\title{
The effects of moisture and temperature on the degradation of sulfentrazone
}

\author{
Camila Ortiz Martinez ${ }^{a}$, Célia Maria Maganhotto de Souza Silva ${ }^{\text {a }}$, Elisabeth Francisconi Fay ${ }^{\text {a,* }}$, \\ Rosângela Blotta Abakerli ${ }^{\mathrm{c}}$, Aline de Holanda Nunes Maia ${ }^{\mathrm{a}}$, Lucia Regina Durrant ${ }^{\mathrm{b}}$ \\ a Embrapa Meio Ambiente, Rodovia SP 340, Km 127.5, Caixa Postal 69, CEP: 13820-000 Jaguariúna, SP, Brazil \\ ${ }^{\mathrm{b}}$ Faculdade de Engenharia de Alimentos, Unicamp, Rua Monteiro Lobato 80, Caixa Postal 6121, CEP: 13083862 Campinas, SP, Brazil \\ c Centro Pluridisciplinar de Pesquisas Químicas, Biológicas e Agrícolas, Unicamp, Caixa Postal 6171, CEP: 13081-970 Campinas, SP, Brazil
}

\section{A R T I C L E I N F O}

\section{Article history:}

Received 12 December 2007

Received in revised form 11 June 2008

Accepted 24 July 2008

Available online 30 August 2008

\section{Keywords:}

Herbicide

Microorganisms

Sulfentrazone

Degradation

Half-life

\begin{abstract}
A B S T R A C T
This study examined the degradation of sulfentrazone in Arenic Hapludult soil, such soil being representative of regions where sulfentrazone is used in Brazil. Soil samples were supplemented with the herbicide [0.7 $\mu \mathrm{g}$ active ingredient (a.i.) $\mathrm{g}^{-1}$ soil] and maintained at $27^{\circ} \mathrm{C}$. The soil moisture content was corrected to 30,70 or $100 \%$ of water holding capacity (WHC). Herbicide-free soil samples were used as controls. Aliquots were taken after 14, 30, 60, 120, 180 and 255 days of incubation for the quantitative analysis of sulfentrazone residues by gas chromatography. Another experiment was conducted using soil samples with and without herbicide, submitted to different temperatures of 15,30 and $40{ }^{\circ} \mathrm{C}$, and kept at a constant value for WHC of $70 \%$. The sulfentrazone residues were quantified by gas chromatography after $14,30,60$ and 120 days of incubation. The potential degrader microorganisms were isolated and identified. A half-life of 172.4 days was estimated at $27^{\circ} \mathrm{C}$ and $70 \%$ WHC. The microorganisms identified as potential degraders of the herbicide were Acinetobacter calcoaceticus, Chrysosporium sp., Eupenicillium sp., Metarhizium sp. and Paecilomyces sp. After 120 days, temperature had no further effect $(P<0.16)$ on sulfentrazone degradation, and the soil moisture content had no effect on degradation at any time.
\end{abstract}

(C) 2008 Elsevier B.V. All rights reserved.

\section{Introduction}

Sulfentrazone ( $\mathrm{N}$-[2,4-dichloro-5-[4-(difluoromethyl)-4,5-dihydro-3 methyl-5-oxo-1H-1,2,4-triazol-1-il] methanesulfonamide), is a member of the phenyl triazolinone herbicide group (Theodorides et al., 1992). This herbicide group controls weeds by inhibiting the enzyme protoporphyrinogen oxidase, a key intermediate in both heme and chlorophyll biosynthesis in plants (Jacobs and Jacobs, 1987; FMC Corporation, 1995; Reddy and Locke, 1998). This herbicide is applied pre-plant incorporated or pre-emergence, and its behaviour in the soil can impact on both weed control efficiency and on the fate of the environment (Reddy and Locke, 1998). It is used for controlling several species of dicotyledonous and monocotyledonous weeds associated with the sugarcane and soybean (Glycine max L.) crops (Dirks et al., 2000; Niekamp and Johnson, 2001). The herbicide is commonly applied by spraying and may be partly adsorbed by soil colloidal particles, leached and degraded by physical, chemical and biological processes, or absorbed by plants (Velini, 1992). All these processes are dependent on the soil and the climatic conditions, and also on the characteristics of the herbicide. Sorption is one of the processes controlling degradation of the herbicide, and has been extensively characterized in soils developed in non-tropical climates. However, there is little information about the

\footnotetext{
* Corresponding author. Tel.: +55 19 33112637; fax: +55 1933112640 E-mail address: bethfay@cnpma.embrapa.br (E.F. Fay).
}

herbicide sorption process in tropical soils, which are chemically and physically distinct from non-tropical soils.

In tropical regions, higher temperatures are observed in the profile of the surface soil layers, resulting in greater organic matter decomposition and an accumulation of iron and aluminum oxides due to the higher weathering rates. Higher clay contents in relation to the silt also predominate (Silva et al., 1998).

Sulfentrazone is a weak acid with a dissociation constant ( $\mathrm{pKa}$ ) of 6.56 (FMC Corporation, 1989). Consequently, at pH values below 6.56, sulfentrazone is predominantly present as neutral molecules and, at $\mathrm{pH}$ values above 6.56, as anionic molecules. In water, the solubility of sulfentrazone decreases by two orders of magnitude between $\mathrm{pH} 7.5$ and 6.0 (16,000 $\mathrm{mg} \mathrm{L}^{-1}$ at $\mathrm{pH} 7.5 ; 780 \mathrm{mg} \mathrm{L}^{-1}$ at pH 7.0 and $110 \mathrm{mg} \mathrm{L}^{-1}$ at pH 6.0) (FMC Corporation, 1995). Conversely, glyphosate is a weak acid herbicide ( $\mathrm{pKa}$ 5.6) that does not undergo significant changes in solubility with changes in $\mathrm{pH}\left(15,700 \mathrm{mg} \mathrm{L}^{-1}\right.$ at $\mathrm{pH} 7 ; 11,600 \mathrm{mg} \mathrm{L}^{-1}$ at $\mathrm{pH} 2.5$ ) (Vencill 2002). In general, the lower the water solubility of the compound, the greater is its sorption to soil solids (Chiou et al., 1983). Acidic herbicide sorption to organic soil colloids is $\mathrm{pH}$ dependent, and greater sorption is observed under acid conditions when pesticides are sorbed in the molecular form (Weber, 1972). This sorption pHdependence has been reported for many acidic pesticides (Spadotto and Hornsby, 2003).

Sorption, physical, chemical and microbial degradation processes are known to be affected by temperature (Walker and Barnes, 1981; Hulscher and Cornelissen, 1996; Paraíba et al., 2003). Laabs et al. 
(2002) reported faster pesticide degradation rates in tropical soils in comparison to the rates found in temperate climates, due to increased microbial populations and activities under the modified environmental conditions, as a result of higher soil temperatures. The primary method of sulfentrazone soil dissipation is considered to be microbial degradation, and the reported half-life $\left(\mathrm{DT}_{50}\right)$ ranges between 110 and 280 days, depending on the soil and environmental conditions (Hatzios, 1998). However, detailed research results on the dissipation and degradation of this compound under tropical conditions are currently unavailable in the referable literature.

The herbicide sulfentrazone is highlighted as the object of this study because it is one of the most used herbicides in the main crops grown in the State of São Paulo, Brazil: soybeans and sugarcane (Fairbanks, 2005). The objective of this work was to evaluate the degradation of this herbicide in Arenic Hapludult soil samples submitted to different moisture and temperature conditions, and to isolate and identify potential degrader microorganisms from this soil.

\section{Materials and methods}

The biotransformation of sulfentrazone was evaluated in Arenic Hapludult (AH) soil samples (USDA, 1975), and the investigation consisted of two separate laboratory soil incubations. The first incubation experiment tested the effects of moisture variations and the second, the effects of temperature variations on the biotransformation of sulfentrazone, using the product concentration recommended for field use in both tests. For this study, the soil samples were collected from areas that had no previous register of sulfentrazone application. The soil studied presented the chemical and physical characteristics described in Table 1.

\subsection{Soils and treatments}

\subsubsection{Effect of moisture variations}

Ten soil subsamples were collected at random from a depth of $0-10 \mathrm{~cm}$. In the laboratory the subsamples were mixed and homogenized to form a composite sample, and then air-dried, sieved ( $2 \mathrm{~mm}$ mesh) and refrigerated at $4{ }^{\circ} \mathrm{C}$ before the incubation tests. The soil $\mathrm{pH}$, residual moisture content and water holding capacity (WHC) were determined according to the methods proposed by Embrapa (1997). One hundred and fifty grams of the composite soil sample was transferred to $500 \mathrm{ml}$ Erlenmeyer flasks and corrected for the humidity to give 30,70 and $100 \% \mathrm{WHC}$, and maintained at $27{ }^{\circ} \mathrm{C}$ for seven days before adding the herbicide. At the end of this period, technical grade sulfentrazone ( $92 \%$ purity) was applied by mixing an aqueous suspension into the experimental units at the same soil concentration rate used in the field $\left(0.7 \mu \mathrm{g} \mathrm{g}^{-1}\right.$ soil $)$, and maintaining the desired soil moisture levels. The experimental units were periodically monitored for soil moisture contents and maintained at the three established levels. Soil samples without the addition of

Table 1

Chemical properties and granulometric analysis for the Arenic Hapludult soil ${ }^{\mathrm{a}}$

\begin{tabular}{ll}
\hline Physicochemical properties & Measured values \\
\hline V\% & 18 \\
Aluminum $\left(\mathrm{mmol} \mathrm{dm}^{-3}\right)$ & 11 \\
Potential acidity $\left(\mathrm{mmol} \mathrm{dm}^{-3}\right)$ & 58 \\
Cation exchange capacity $\left(\mathrm{mmol} \mathrm{dm}^{-3}\right)$ & 71 \\
Sum of bases $\left(\mathrm{mmol} \mathrm{dm}^{-3}\right)$ & 13 \\
Organic matter $\left(\mathrm{g} \mathrm{dm}^{-3}\right)$ & 21 \\
pH in water & 5.44 \\
Clay $\left(\mathrm{g} \mathrm{kg}^{-1}\right)$ & 221 \\
Silt $\left(\mathrm{g} \mathrm{kg}^{-1}\right)$ & 98 \\
Total sand $\left(\mathrm{g} \mathrm{kg}^{-1}\right)$ & 681 \\
Textural classification & Sandy clay loam \\
\hline
\end{tabular}

\footnotetext{
a Arenic Hapludult (USDA Soil Conservation Service, Soil Survey Staff, 1975).
}

b Base saturation. herbicide were used as the controls. Three replicate flasks were used for each treatment. Soil samples were taken 14, 30, 60, 120, 180 and 255 days after treatment, and evaluated using gas chromatography to determine the amount of herbicide degraded.

\subsubsection{Effect of temperature variations}

Another experiment was carried out using soil samples with $\left(0.7 \mu \mathrm{g} \mathrm{g}^{-1}\right.$ soil) and without the addition of herbicide, all corrected for soil moisture content at the $70 \%$ WHC level and incubated at three different temperatures: 15,30 and $40{ }^{\circ} \mathrm{C}$. Three replicates were made for each treatment. The residues of sulfentrazone were quantified by gas chromatography after 14, 30, 60 and 120 days of incubation.

\subsection{Extraction and analysis of residual sulfentrazone and its metabolites from the soil samples}

Soil samples ( $10 \mathrm{~g}$ ) were taken from the experimental units at the same sampling times mentioned earlier for the different incubation periods, and submitted to extraction in a reflux system using $150 \mathrm{ml}$ of a $(3: 1, v / v)$ acetone:hydrochloric acid solution $\left(0.25 \mathrm{~mol} \mathrm{l}^{-1}\right)$ for $1 \mathrm{~h}$. After reaching room temperature, the samples were filtered through, Whatman no.1 filter paper (pre-rinsed with $5 \mathrm{ml}$ of acetone) using Büchner funnels. The filtrate was quantitatively transferred to a round-bottom flask $(250 \mathrm{ml})$ and evaporated to about $25 \mathrm{ml}$ at $40{ }^{\circ} \mathrm{C}$ using a rotating vacuum evaporator. The final volume was adjusted to $100 \mathrm{ml}$ with bidistilled water. The aqueous extract was purified and concentrated using two different absorbents $\left(\mathrm{C}_{8}\right.$ and silica gel) in a Manifold system.

Aliquots $(25 \mathrm{ml})$ of the extracts were submitted to a clean-up process that was initially carried out in the $\mathrm{C}_{8}$ absorbent, pre-conditioned with $3 \mathrm{ml}$ of methanol followed by $3 \mathrm{ml}$ of $0.25 \mathrm{~N} \mathrm{HCl}$. The flow rate through the $C_{8}$ cartridge was maintained at $2 \mathrm{ml} \mathrm{min}^{-1}$. The cartridge was then closed and another $1.5 \mathrm{ml}$ of $0.25 \mathrm{~N} \mathrm{HCL}$ added. The sample was then passed through the $C_{8}$ cartridge, which was subsequently blown completely dry. In this step, the analyte of interest was retained in the absorbent. This analyte was then eluted to a silica-gel cartridge using $3 \mathrm{ml}$ hexane-ethyl acetate $(19: 1, \mathrm{v} / \mathrm{v})$, the silica-gel cartridge having been conditioned with $3 \mathrm{ml}$ of ethyl-acetate followed by $3 \mathrm{ml}$ of hexane. The flow rate through the silica-gel cartridge was maintained at $2 \mathrm{ml}$ $\mathrm{min}^{-1}$. The cartridge was then closed and $1 \mathrm{ml}$ of hexane-ethyl acetate $(7: 3, v / v)$ added. The $C_{8}$ cartridge was then attached to the top of the silica-gel cartridge using a reducing adapter and $3 \mathrm{ml}$ of hexane-ethyl acetate $(7: 3, v / v)$ added to the $C_{8}$ cartridge, followed by an additional $3 \mathrm{ml}$ of hexane-ethyl acetate $(7: 3, \mathrm{v} / \mathrm{v})$. After the $\mathrm{C}_{8}$ eluate had reached the top of the silica-gel cartridge packing, the $C_{8}$ cartridge was removed and discarded. The silica-gel cartridge was then washed with $3 \mathrm{ml}$ of hexane-ethyl acetate $(7: 3, v / v)$. The analytes were eluted from the silicagel cartridge using $6 \mathrm{ml}$ ethyl-acetate and collected in a glass tube. The silica-gel cartridge was then discarded and the solvent evaporated to near dryness $( \pm 0.5 \mathrm{ml})$ using an evaporation system under a nitrogen flow. The extract was finally resuspended in acetone to a final volume of $5 \mathrm{ml}$.

The samples were analyzed by gas chromatography using an Agilent model 6890 gas chromatograph equipped with a splitless injection system at $250{ }^{\circ} \mathrm{C}$ and a $\mu \mathrm{ECD}$ electron capture detector with the temperature adjusted to $300^{\circ} \mathrm{C}$. The analyte was separated in a DB 608 megabore column $(30 \mathrm{~m} \times 0.53 \mathrm{~mm} \times 0.83 \mu \mathrm{m})$ with a nitrogen flow of $16 \mathrm{ml} \mathrm{min}^{-1}$ and an initial oven temperature of $180^{\circ} \mathrm{C}$, maintained for $1 \mathrm{~min}$, followed by a heating ramp of $20^{\circ} \mathrm{C} \mathrm{min}^{-1}$ to $250{ }^{\circ} \mathrm{C}$ and finally $5^{\circ} \mathrm{C} \mathrm{min}^{-1}$ to $260{ }^{\circ} \mathrm{C}$. The retention time for sulfentrazone was $8.8 \mathrm{~min}$.

Each set of analyses contained a minimum of one control sample, two fortified control samples and the treated samples. Each treatment was replicated three times. The sulfentrazone standard curve $(0.01$ to $\left.0.1 \mu \mathrm{g} \mathrm{ml}^{-1}\right)$ was linear $\left(r^{2}=0.9933 ; n=5\right.$; data not shown $)$. Chromatograms of the soil extracts showed no major peaks eluting in the retention window of sulfentrazone (data not shown). 
The efficiency of the method applied was evaluated and validated by the acceptable and reproducible pesticide recoveries from the fortified control samples (Table 2). The detection limit (LOD) was fixed at $0.01 \mu \mathrm{g} \mathrm{ml} \mathrm{m}^{-1}$ and the limit of quantification (LOQ) was $0.05 \mathrm{mg} \mathrm{kg}^{-1}$; validation in the soil being carried out at the spike level of $0.05 \mathrm{mg} \mathrm{kg}^{-1}$ (Lee, 2003).

The metabolite 3-hydroxymethylsulfentrazone (HMS) was identified by high performance liquid chromatography (HPLC). In this case, the organic phase (acetone) of the purified samples was evaporated using an evaporation system under a nitrogen flow at $45^{\circ} \mathrm{C}$, and the samples were resuspended in acetonitrile. The chromatographic conditions were as follows: Shimadzu chromatograph, C18 reverse-phase column, flow of $1 \mathrm{ml} \mathrm{min}{ }^{-1}$, room temperature, detection using a diode array detector (DAD), UV $254 \mathrm{~nm}, 24: 75$ to $60: 40$ gradient in $60 \mathrm{~min}$, with the mobile phase consisting of $0.5 \%$ acetonitrile and acetic acid.

\subsection{Isolation and characterization of sulfentrazone degraders}

The enriched soils (10 g) with and without the addition of sulfentrazone, incubated for 120 days at $27{ }^{\circ} \mathrm{C}$ and $70 \%$ WHC, were aseptically suspended in $90 \mathrm{ml}$ of distilled water for 2 min using a Vortex mixer. Serial dilutions of the suspensions $\left(10^{-2} ; 10^{-3}\right.$ and $\left.10^{-4}\right)$ were transferred to a minimal medium $\left(\mathrm{NaNO}_{3} 3 \mathrm{~g} ; \mathrm{K}_{2} \mathrm{HPO}_{4} 1 \mathrm{~g}\right.$; $\mathrm{MgSO}_{4} \cdot 7 \mathrm{H}_{2} \mathrm{O} 0.5 \mathrm{~g} ; \mathrm{KCl} 0.5 \mathrm{~g} ; \mathrm{FeSO}_{4} \cdot 7 \mathrm{H}_{2} \mathrm{O} 0.01 \mathrm{~g}$; agar $16 \mathrm{~g} ; \mathrm{H}_{2} \mathrm{O}$ $1000 \mathrm{ml})$ and sulfentrazone $\left(0.7 \mu \mathrm{g}\right.$ i.a ml ${ }^{-1}$ medium $)$ added as the sole carbon and energy source. Herbicide-free medium was used as the control. The organic compound was added at room temperature after autoclaving. After incubation for 2; 7 and 17 days at $27{ }^{\circ} \mathrm{C}$, the individual colonies of bacteria, actinomycetes and fungi grown in the medium were respectively picked and transferred to new minimum liquid medium $(99 \mathrm{ml})\left(\mathrm{NaNO}_{3} 3 \mathrm{~g} ; \mathrm{K}_{2} \mathrm{HPO}_{4} 1 \mathrm{~g} ; \mathrm{MgSO}_{4} \cdot 7 \mathrm{H}_{2} \mathrm{O} 0.5 \mathrm{~g} ; \mathrm{KCl}\right.$ $0.5 \mathrm{~g} ; \mathrm{FeSO}_{4} \cdot 7 \mathrm{H}_{2} \mathrm{O} 0.01 \mathrm{~g} ; \mathrm{H}_{2} \mathrm{O} 1000 \mathrm{ml}$ ). After serial dilution, $1 \mathrm{ml}-$ aliquots of the $10^{-1}$ dilution were inoculated into Erlenmeyer flasks $(250 \mathrm{ml})$ containing $99 \mathrm{ml}$ of the same medium plus the herbicide at different concentrations $\left(2.1 ; 4.2\right.$ and $7.0 \mu \mathrm{g}$ i.a $\mathrm{ml}^{-1}$ medium). The cultures were transferred three times over a fifty day period. The microorganisms were isolated after vortexing in a $0.1 \%$ Tween 80 solution and streaking on solid medium. The purified strains were then tested in a medium containing sulfentrazone ( $7.0 \mu \mathrm{g}$ i.a $\mathrm{ml}^{-1}$; and ten-fold the field rate) as the sole carbon source.

The isolated bacterial and actinomycetes strains were identified by an analysis of their fatty acid methyl esters (FAMEs) using the Microbial Identification System developed by Microbial ID (Midi, 2001). Cell fatty acids were extracted according to Sasser (1990). Fatty acid methyl esters from each strain were separated using a Hewlett-Packard gas chromatography model fitted with a fused silica column $(25 \mathrm{~m} \times 0.2 \mathrm{~mm}$ internal diameter). FAME peaks were named by the MISsoftware, and bacterial strains were identified using the MIS "Aerobia Library" (Version TSBA50). The fungal stock cultures were maintained at $4{ }^{\circ} \mathrm{C}$ on Sabourad medium (Tuite, 1969). The procedure for the strain identification was adapted from Nogueira and Barroso (1998) for visualization; and the images were obtained by scanning electron microscopy and identified with the help of a specific manual (Barnett and Hunter, 1972).

\subsection{Statistical analysis}

The effects of the moisture level and incubation period on the residual amount of sulfentrazone (RASulf) were investigated using the

Table 2

Fortification levels and recovery (\%) of sulfentrazone in soil samples

\begin{tabular}{lll}
\hline Matrix & Fortification level & Recovery (\%) \\
\hline Soil & $0.05 \mathrm{mg} \mathrm{kg}^{-1}$ & 111 \\
Soil & $0.05 \mathrm{mg} \mathrm{kg}^{-1}$ & 106 \\
Soil & $0.7 \mathrm{mg} \mathrm{kg}^{-1}$ & 120 \\
\hline
\end{tabular}

\section{Table 3}

Mean values for the remaining amount of sulfentrazone $\left(\mu \mathrm{g} \mathrm{g}^{-1}\right)$ in an Arenic Hapludult soil with time, under different moisture levels (\% WHC)

\begin{tabular}{llllll}
\hline Moisture (\% WHC) & \multicolumn{5}{l}{ Mean values for the remaining amount of sulfentrazone $\left(\mu \mathrm{g} \mathrm{g}^{-1}\right)$} \\
\cline { 2 - 6 } & 30 & 60 & 120 (days) & 180 & 255 \\
\hline 30 & 0.90 & 0.77 & 0.41 & 0.36 & 0.26 \\
70 & 0.62 & 0.62 & 0.40 & 0.37 & 0.16 \\
100 & 0.60 & 0.64 & 0.60 & 0.50 & 0.44 \\
\hline
\end{tabular}

analysis of variance and Snedecor's $F$ tests (Montgomery, 1991). The same analysis was performed to evaluate the effect of temperature on RASulf. The influence of temperature and moisture level on the mean degradation rate was quantified by RASulf on the last evaluation date, since the initial amount $\left(0.7 \mu \mathrm{g} \mathrm{g}^{-1}\right)$ was constant for all treatments. To accomplish this, $t$ tests were performed for contrasts between the RASulf means at different temperature and moisture levels.

The analyses of variance and $t$ tests for the contrasts were performed using the SAS System's MIXED Procedure (SAS, 2004).

When the differences between the RASulf means were significant for any of the contrasts evaluated, the temperature or moisture factor level was selected for the lowest RASulf (highest degradation rate) to fit the degradation models and estimate the half-life values. A linear model was used (Eq. (1)):

$R(t)=1-\beta \cdot t+\varepsilon ; \beta>0$

where, $R(t)$ is the sulfentrazone percentage remaining at time $t, \beta$ is a parameter related to the velocity of degradation in the descending phase, and $\varepsilon$ is the random error associated with each observation. The half-life corresponds to the $t$ value for which the predicted value for $R(t)$ is equal to 0.50 . The Gauss-Newton method (Bard, 1970), implemented in the SAS System's Proc NLIN (SAS, 2004), was used to fit the model. This procedure was used since this type of model, although linear, has a restriction because the intercept is equal to one.

The herbicide effect on the soil microbiota, measured from the number of colony-forming units (CFU), was evaluated by comparing the mean number of CFUs in soil samples with and without sulfentrazone using the Student's test with Satterthwaite's approximation (Satterthwaite, 1946). The TTEST Procedure of the SAS System (SAS, 2004) was used.

\section{Results}

The mean values for the residual amounts of sulfentrazone $\left(\mu \mathrm{g} \mathrm{g}^{-1}\right)$ in the Arenic Hapludult soil samples with time, at different moisture

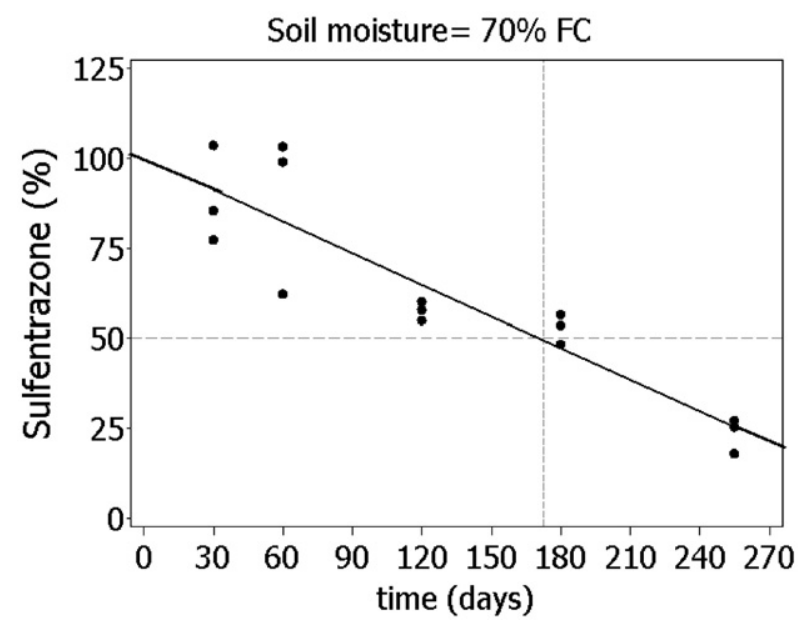

Fig. 1. Sulfentrazone degradation in an Arenic Hapludult soil with time at $27^{\circ} \mathrm{C}$ and $70 \%$ FC. The dotted vertical line indicates the half-life value: 172.41 days ( - fitted linear model, $\bullet$ observed values). 
Table 4

Estimates of contrasts between mean remaining sulfentrazone concentrations ( $\mu \mathrm{g} \mathrm{g}^{-1}$ ) under different temperatures, at 120 days

\begin{tabular}{llll}
\hline Temperature & Estimate $\left(\mu \mathrm{g} \mathrm{g}^{-1}\right) \mathrm{day}^{-1}$ & Standard error $\left(\mu \mathrm{g} \mathrm{g}^{-1}\right)$ day $^{-1}$ & $P$ value $^{\mathrm{a}}$ \\
\hline $15^{\circ}$ & 0.0023 & 0.0007 & 0.0028 \\
$30^{\circ}$ & 0.0015 & 0.0007 & 0.0418 \\
$40^{\circ}$ & 0.0016 & 0.0007 & 0.0330 \\
\hline
\end{tabular}

${ }^{\mathrm{a}}$ Nominal significance level of $t$ test for contrasts.

levels (\%WHC), showed there was no significant effect of the moisture level on sulfentrazone degradation ( $t$ test for contrasts; $P>0.45$ ) (Table 3). However, the degradation rates decreased in soil samples with 100\% WHC and 180 days of incubation. Soil samples with 30 and $70 \%$ WHC showed lower degradation rates earlier (120 days of incubation). According to the data observed, the greatest dissipation level of the herbicide sulfentrazone was $76.4 \%\left(\right.$ RASulf $\left.=0.16 \mu \mathrm{g} \mathrm{g}^{-1}\right)$, after 255 days of incubation in soil samples with 70\% WHC (Table 3). Under these conditions, the estimated half-life for sulfentrazone was 172.4 days. The fitted degradation curve is presented in Fig. 1 and the estimate for parameter $\beta$ of the corresponding model was 0.003 .

An analysis of the contrasts between the degradation rates indicated no significant effect of temperature ( $t$ test for contrasts; $P>0.41$ ) (Table 4). Therefore, the degradation rate results will be discussed without considering the effect of temperature and the rate value estimations will be done using linear regression.

As the true initial herbicide concentration was known $\left(0.7 \mu \mathrm{g} \mathrm{g}^{-1}\right)$, the remaining herbicide concentrations after 120 days were expressed as a \% of the true initial concentration and used as an indicator of dissipation. In fact, the contrasts between the means of the residual concentrations after 120 days were made using the whole data set, in order to estimate the mean square errors required to perform the $t$ tests, thus accounting for the overall data variability.

Although, the analyses to detect the parent compounds and metabolites were done on all the sampling dates, the presence of the metabolite 3-hydroxymethyl sulfentrazone (HMS) was only observed after a 180-day-incubation period in the soil samples incubated at $40{ }^{\circ} \mathrm{C}$ with a $70 \%$ WHC level. Sulfentrazone is converted to HMS in soils in temperate regions and HMS has a high leaching potential. Considering the importance of knowing the behaviour of this herbicide with respect to the environment in soils in tropical regions and the commercial unavailability of HMS, this compound was isolated from rat's urine after administering the herbicide to the rats (Leung et al., 1991). The proposed mammalian metabolic pathway is the conversion of the parent compound mainly to 3-HMS (88-95\%), which is excreted in the urine. Therefore the metabolite 3-hydroxymethylsulfentrazone (HMS) was identified as the peak that showed a mean retention time of $12.52 \mathrm{~min}$. The transformed product can only be identified from MS/MS data, but not quantified. The HMS presented a mass of

Table 5

Evaluation of the effect of the herbicide sulfentrazone on the mean number of microbial colony-forming units isolated in an Arenic Hapludult soil

\begin{tabular}{|c|c|c|c|c|c|}
\hline Organisms & $\begin{array}{l}\text { Sulfentrazone } \\
\left(0.7 \mu \mathrm{g} \mathrm{g}^{-1}\right)\end{array}$ & $\begin{array}{l}\text { Mean }^{a} \\
(\mathrm{CFU})\end{array}$ & Lower limit $^{\mathrm{a}}$ & Upper limit ${ }^{\mathrm{a}}$ & $P$ value $^{\mathrm{b}}$ \\
\hline Actinomycete & Absent & 303 & 117 & 490 & \\
\hline Actinomycete & Present & 697 & 342 & 1052 & \\
\hline Actinomycete & Difference $^{c}$ & 393 & & & 0.02 \\
\hline Bacterium & Absent & 1047 & 588 & 1505 & \\
\hline Bacterium & Present & 1440 & 961 & 1919 & \\
\hline Bacterium & Difference & 393 & & & 0.06 \\
\hline Fungi & Absent & 22 & -14 & 59 & \\
\hline Fungi & Present & 3 & -0.2 & 6 & \\
\hline Fungi & Difference & -20 & & & 0.15 \\
\hline
\end{tabular}

Application of Student's $t$ test.

a Value 1000 times smaller than the observed.

b $P$ value relative to the $t$ test.

c Difference between numbers of CFU in samples with or without sulfentrazone.
Table 6

Identification of bacterial strains using MIS, in an Arenic Hapludult Soil (AHS)

\begin{tabular}{llll}
\hline Soil/isolate no. & $\begin{array}{l}\text { Sulfentrazone } \\
\left(\mu \mathrm{ml}^{-1}\right)\end{array}$ & $\begin{array}{l}\text { Identification of single colonies } \\
*\end{array}$ & $\begin{array}{l}\text { Library } \\
\text { matches }\end{array}$ \\
\hline AHS 3 & 7.0 & Acinetobacter calcoaceticus & 0.827 \\
AHS 5 & 7.0 & Acinetobacter calcoaceticus & 0.771 \\
AHS 8 & 7.0 & Acinetobacter calcoaceticus & 0.785 \\
AHS 6 & 7.0 & Acinetobacter calcoaceticus & 0.814 \\
AHS 7 & 7.0 & Acinetobacter calcoaceticus & 0.791 \\
AHS 2A & 7.0 & Acinetobacter calcoaceticus or & $0.773 /$ \\
& & Acinetobacter radioresistens & 0.705 \\
AHS 4 & 7.0 & Acinetobacter calcoaceticus & 0.792 \\
AHS 1 & 7.0 & Acinetobacter calcoaceticus & 0.795
\end{tabular}

*These microorganisms were isolated in a medium supplemented with sulfentrazone $\left(7 \mu \mathrm{g} \mathrm{ml}^{-1}\right)$, as a sole carbon and energy source.

**Library matches are expressed on a scale of 0 to 1 , with a match of 0.5 or greater considered good to the species level (Olson, 1996).

402 and the molecular ions $(M+1)$ were reported in a $m / z$ ratio of 403 . Therefore, this product should only be used as a standard in studies related to the identification of the metabolite in soil and not for its quantification.

The growth of bacteria and specifically actinomycetes was favoured by the presence of the herbicide: increases of $3.93 \cdot 10^{5}$ CFUs being observed in both cases ( $t$ test; $P<0.06$ ). For fungi there was little evidence of any effect of the herbicide on the number of CFUs $(P=0.15)$ (Table 5).

With respect to fungi, the strains isolated from the control soil were all Penicillium sp., whereas the strains isolated and identified from the soil with added sulfentrazone $\left(7.0 \mu \mathrm{g} \mathrm{g}^{-1}\right)$ were: Chrysosporium sp., two strains of Eupenicillium sp., Metarrhizium sp. and Paecilomyces sp. Taking into consideration the concentration of herbicide used (10x field concentration) in the laboratory tests to determine the sideeffects of pesticides on soil microflora (recommended by Sommerville, 1987), the selection made by the herbicide permitted the identification of these strains as possible herbicide degraders.

Similar results were obtained with bacteria. The bacterial strains of Acinetobacter calcoaceticus (Table 6) that grew at $7.0 \mu \mathrm{g}$ of sulfentrazone $\mathrm{ml}^{-1}$ of culture medium as the sole source of carbon and energy, were selected as potential sulfentrazone degraders.

\section{Discussion}

Sulfentrazone is among the most widely used herbicides in the main crops grown in the State of São Paulo. However, no studies are available on the biotransformation of this compound in Brazilian soils, which is an important aspect to be exploited due to the characteristics of the herbicide and its contamination potential (Agrofit, 2004; EPA, 2003). According to the Environment and Renewable Natural Resources Institute ("Instituto do Meio Ambiente e dos Recursos Naturais Renováveis" - Ibama, 1990), this compound was classified as a medium-persistence herbicide (with a half-life between 90 and 180 days), which corroborates the half-life value obtained in the present study, of 172.4 days at $27^{\circ} \mathrm{C}$ and $70 \%$ WHC, close to the average value found under natural field conditions. Sulfentrazone has medium to high persistence, and precautions are required with respect to the application intervals, allowing sufficient time for dissipation, thus minimizing the risk of damage to crops and non-target species (Alves et al., 2004).

Ohmes et al. (2000) showed that microbial degradation is an important mechanism for sulfentrazone dissipation, since its degradation was very slow in autoclaved soils. Reddy and Locke (1998) demonstrated a low potential for the biotransformation of this herbicide in soils that had not previously been exposed to it. According to Alexander (1999), when an agrochemical that is susceptible to microbial degradation is applied to the soil for the first time, an adaptation period of the microorganisms to the molecule is required 
before degradation can occur at significant rates. It is during this phase that these organisms produce the compound degrading enzymes; this is followed by an enrichment period, in which the adapted microorganisms multiply using the substrate as a source of carbon and energy. In the present experiment, since the soil used had no prior contact with sulfentrazone, the above-mentioned adaptation phase (lag phase) of the microorganisms to the compound was observed, which varied according to the treatments (temperature and moisture) used. After the adaptation period, the microorganisms were capable of degrading the herbicide, as indicated by the presence of the metabolite 3-hydroxymethyl sulfentrazone. The presence of this compound is the evidence that some microbial degradation is occurring in the soil and that either fungi or bacteria can metabolize the herbicide.

The formation of this derivative is known to be achieved through a stepwise oxidation of the triazolinone ring methyl group of the parent molecule, and it is known to be less toxic than sulfentrazone (Dayan et al., 1996, 1998) with respect to its biological activity (Theodorides et al., 1992). The metabolisms of sulfentrazone in animals and plants are similar; the major plant metabolite being 3-hydroxymethyl sulfentrazone (HMS). The degradation products formed can constitute an extremely complex blend of substances. Other metabolites include sulfentrazone carboxylic acid (SCA) and 3-desmethylsulfentrazone (DMS) (EPA, 2003). However, the lack of analytical standards represents another problem.

Despite the lack of information in the literature about the degradation route of sulfentrazone by microorganisms, the disappearance of the parent compound coincidently with the appearance of the metabolite at the end of the experimental period is in accordance with the metabolism of the herbicide in both plants and animals. Consequently, HMS is also part of the metabolic degradation route of this herbicide by microorganisms.

The activities of degrader microorganisms can be influenced by soil parameters such as temperature and moisture. Moisture has a direct effect on the proliferation of microorganisms and on their activities, and they compete with the herbicides for adsorption sites, determining the amount of product available for microbial attack, while temperature is important for its direct thermodynamic effect on cell metabolism, and on the main physical and chemical properties of the microenvironment.

In this research, the results concerned the effect of moisture on herbicide degradation were not significant between the different moisture levels, but the degradation was higher than $76 \%$ at a $70 \%$ WHC level after 255 days, with a half-life $\left(\mathrm{DT}_{50}\right)$ of 172.4 days. A slower herbicide degradation $(<45 \%)$ was observed for the $100 \%$ WHC. Other studies have reported a decrease in the percent dissipation of pesticides under anaerobic conditions. For example, the dissipation of the insecticide DDT (dichlorodiphenyltrichloroethane) in soil with moisture contents of 75 and $100 \%$ of the WHC was 12 and $3 \%$, respectively (Andrea et al., 1994). Ohmes et al. (2000) observed that the dissipation of sulfentrazone in the field was more rapid, with a $\mathrm{DT}_{50}$ of 25 days, when the rainfall was above normal. With more rain, sulfentrazone could have moved below the sampling zone. However, the application was not preceded by heavy rain, and with a soil $\mathrm{pH}$ of 6.1, which is below the $\mathrm{pKa}$ of sulfentrazone of 6.56 , there should have been minimal movement due to increased adsorption at the lower $\mathrm{pH}$ levels (Grey et al., 1997). A lower $\mathrm{DT}_{50}$ value under these conditions is consistent with the laboratory data that suggested the microbial degradation of sulfentrazone.

Degradation and sorption are the main processes controlling the fate of herbicides in soil and are often the focus of leaching potential assessments (Jury et al., 1987; Gustafson, 1989). The degradation and sorption of organic molecules are coupled processes (Scow and Johnson, 1997), where an increase in sorption generally results in a decrease in microbial degradation (Ogram et al., 1985; Sims et al., 1991; Sims et al., 1992; Krieger et al., 1998). For most compounds, there is evidence that microbial degradation occurs preferentially in the aqueous phase (Ogram et al., 1985). Comparing the results for the degradation of the herbicide sulfentrazone in $\mathrm{AH}$ soil with that in other Brazilian soils, it was observed that this soil presented a lower degradation rate and consequently higher compound persistence. In a typical Hapludox soil the half-life of sulfentrazone was 146.5 days at $27{ }^{\circ} \mathrm{C}$, and for the Rhodic Hapludox soil it was 91.6 at $30^{\circ} \mathrm{C}$ (Martinez, 2006). In the $\mathrm{AH}$ soil, the herbicide degradation rates at 30 and $40{ }^{\circ} \mathrm{C}$ were similar $(P>0.03)$, but were higher at $15{ }^{\circ} \mathrm{C}(P<0.003)$. According to Moreale and van Bladel (1979), a decrease in temperature may reduce herbicide adsorption, since the water layer bound to the soil surface is released at higher temperatures, and consequently more adsorption sites become empty and more herbicide is adsorbed at these higher temperatures. The soil moisture content can alter the distribution of sulfentrazone between the soil solution and the sorbed phases.

Although AH presents a more sandy soil texture than the other two soils (a sandy texture accounts for lower compound adsorption), the sulfentrazone presented a longer half-life in this soil. This means a lower sulfentrazone degradation rate, which might be due to the lower metabolic capacity of the microbial flora in relation to this herbicide, or else to the internal stability of its chemical structure.

The $\mathrm{pKa}$ (6.56) of sulfentrazone is higher than the $\mathrm{pH}$ (5.44) of the AH soil, which means that under such conditions, sulfentrazone is a non-ionic molecule and might be adsorbed through various mechanisms such as ion exchange, charge-transfer interaction, hydrogen bonding and van der Walls forces (Koskinen and Harper, 1990).

The sulfentrazone sorption coefficient $(K d)$ estimated for the Arenic Hapludult soil was $1.53 \mathrm{~g} \mathrm{ml}^{-1}$ while that measured experimentally was $2.15 \mathrm{~g} \mathrm{ml}^{-1}$ (Paraíba et al., 2005; Paraíba et al., 2006). The values measured for the soil/water sulfentrazone sorption or partition coefficients in this soil were significantly higher than the estimated values and significantly higher than the observed and estimated values found for two other Brazilian soils (data not shown). The sulfentrazone adsorption levels vary amongst soil types, and the amount of desorption into solution may be soil cation-dependent (Grey et al., 2000).

The presence of sulfentrazone in this agricultural soil increased the total numbers of bacteria and fungi. Thus it has been reported that pesticides are metabolized by different soil microorganisms, which can use their metabolites as a carbon source (Alexander, 1999). This fact is corroborated by the excellent microbial growth in media supplemented with high concentrations of sulfentrazone $\left(7.0 \mu \mathrm{g} \mathrm{ml}^{-1}\right)$ as the only source of carbon and energy, thus indicating the high degrading potential of these strains.

Considering the lack of data on the mineralization and biotransformation of sulfentrazone in native agricultural soils, the proliferation of the bacterial and fungal flora in the treated soil samples might be associated with the transformation of the herbicide by the bacteria and fungi observed in this study. The microorganisms isolated as potential sulfentrazone degraders were A. calcoaceticus, Eupenicillium sp., Paecilomyces sp., Chrysosporium sp., and Metarhizium sp. The bacterial strain $A$. calcoaceticus was selected as a potential sulfentrazone degrader, with a similarity index of $0.771-0.827$, obtained by means of comparison against the 40 TSBA library databases.

Despite the lack of references in the literature about sulfentrazone degrader microorganisms, there are reports on the influence of microorganisms in the degradation of other organic compounds. For example, according to Singh et al. (2004), of five Acinetobacter sp. strains isolated from soil contaminated with atrazine, only one strain could grow in the presence of $250 \mu \mathrm{g} \mathrm{ml}^{-1}$ of the herbicide, using it as a source of carbon and as a secondary source of nitrogen. The same strain was capable of using cyanazine, prometon, simazine, and terbutryn as energy sources. Acinetobacter sp. frequently possesses the enzymatic machinery required to mineralize many organic compounds (Chung et al., 1996; Smithgrenier and Adkins., 1996; Dellamatrice and 
Monteiro, 2004). Penicillium chrysogenum is capable of using the herbicide glyphosate as its only source of nitrogen in a minimal medium. Concentrations above $25 \mathrm{mM}$ stimulated the fungal growth rate (Klimek et al., 2001). Penicillium steckii was selected as a degrader of the herbicide simazine (Kodama et al., 2001).

\section{Conclusion}

In the present study, the half-life value for sulfentrazone obtained in the laboratory was 172.4 days at $27{ }^{\circ} \mathrm{C}$ and $70 \%$ WHC, despite the Arenic Hapludult soil being a very sandy soil, which usually causes lower herbicide adsorption and enhances its molecule biotransformation and leaching. However, the soil pH was low (acid medium), which might have favoured adsorption of the molecule. The overall results obtained in this paper suggested that the degradation of sulfentrazone was influenced by microorganisms.

\section{Acknowledgments}

Financial support for this project was provided by The State of São Paulo Research Foundation (Fundação de Amparo à Pesquisa do Estado de São Paulo - FAPESP). We are indeed grateful for the expert's support to this paper.

\section{References}

Agrofit, 2004. online at: <http://extranet.agricultura.gov.br/agrofit_cons/principal_ agrofit_cons>.

Alexander, M., 1999. Biodegradation and Bioremediation. Academic Press, New York.

Alves, P.L.C.A., Marques Jr., J., Ferraudo, A.S., 2004. Soil attributes and the efficiency of sulfentrazone on control of purple nutsedge (Cyperus rotundus L.). Sci. Agric. 61, 319-325.

Andrea, M.M., Luchini, L.C., Mello, M.H.S.H., Tomita, R.Y., Mesquita, T.B., Mucumeci, M.R., 1994. Dissipation and degradation of DDT and parathion in Brazilian soils. J. Environ. Sci. Health 29, 121-132.

Bard, J., 1970. Comparison of gradient methods for the solution of the nonlinear parameter estimation problem. SIAM J. Numer. Anal. 7, 157-186.

Barnett, H.L., Hunter, B.B., 1972. Illustrated Genera of Imperfect Fungi. Burgess Publishing Company, Minneapolis.

Chiou, C.T., Porter, P.E., Schmedding, D.W., 1983. Partition equilibria of nonionic organic compounds between soil organic matter and water. Environ. Sci. Technol. 17, 227-231.

Chung, N.J., Han, H.J., Lee, H.H., Rhie, H.G., Lee, H.S., 1996. Degradation of phosphonate herbicide glyphosate by Acinetobacter Iwoffii HN401. Mol. Cells 6, 239-245.

Dayan, F.E., Weete, J.D., Hancock, H.G., 1996. Physiological basis for differential sensitivity to sulfentrazone by sicklepod (Senna obtusifolia) and coffee senna (Cassia occidentalis). Weed Sci. 44, 12-17.

Dayan, F.E., Armstrong, B.M., Weete, J.D., 1998. Inhibitory activity of sulfentrazone and its metabolic derivatives on soybean (Glycine max) protoporphyrinogen oxidase. J. Agric. Food Chem. 46, 2024-2029.

Dellamatrice, P.M., Monteiro, R.T.R., 2004. Isolation of diuron-degrading bacteria from treated soil. Braz. Arch. Biol. Technol. 47, 999-1003.

Dirks, J.T., Johnson, W.G., Smeda, R.J., Wiebold, W.J., Massey, R.E., 2000. Use of preplant sulfentrazone in no-till, narrow-row, glyphosate-resistant Glycine max. Weed Sci. $48,628-639$.

Embrapa. Centro Nacional de Pesquisa de Solos, 1997. Manual de Métodos de Análise de Solo. Embrapa Solos, Rio de Janeiro, RJ, Brazil.

EPA, 2003. Federal Register: Sulfentrazone; Pesticide Tolerances. online at: <http:/ www.epa.gov/fedrgstr/EPA-PEST/2003/September/Day-4/p24011.htm>

Fairbanks, M., 2005. Defensivos Agrícolas Ampliam Mercado. online at: <http://www. quimica.com.br/revista/qd396/defensivos_agricolas.htm>.

FMC Corporation, 1989. Technical Bulletin of Sulfentrazone (F6285). Agricultura Chemical Group, Philadelphia, PA.

FMC Corporation, 1995. Technical Bulletin of Sulfentrazone. FMC Corporation, Philadelphia, PA.

Grey, T.L., Walker, R.H., Hancock, H.G., 1997. Sulfentrazone adsorption and mobility affected by soil and $\mathrm{pH}$. Weed Sci. 45, 733-738.

Grey, T.L., Walker, R.H., Wehtje, G.R., Adams Jr., J., Dayan, F.E., Weete, J.D., Hancock, H.G., Kwon, O., 2000. Behavior of sulfentrazone in ionic exchange resins, electrophoresis gels, and cation-saturated soils. Weed Sci. 48, 239-247.

Gustafson, D.I., 1989. Groundwater ubiquity score: a simple method for assessing pesticide leachability. Environ. Toxicol. Chem. 8, 339-357.

Hatzios, K.K., 1998. Supplement to Herbicide Handbook, 7th ed. Weed Science Society of America, Lawrence, KS, pp. 67-69.

Hulscher, T.h.E.M., Cornelissen, G., 1996. Effect of temperature on sorption equilibrium and sorption kinetics of organic micropollutants - a review. Chemosphere 32 , 609-629.

Ibama, 1990. Manual de Testes para Avaliação da Ecotoxicidade de Agentes Químicos, 2nd ed. Ibama, Brasília, DF, Brasil.
Jacobs, J.M., Jacobs, N.J., 1987. Oxidation of protoporphyrinogen to protoporphyrin, a step in chlorophyll and heme biosynthesis. Biochem. J. 244, 219.

Jury, W.A., Focht, D.D., Farmer, W.J., 1987. Evaluation of pesticide groundwater pollution potential from standard indices of soil-chemical adsorption and biodegradation. J. Environ. Qual. 16, 422-428.

Klimek, M., Lejczak, B., Kafarski, P., Forlani, G., 2001. Metabolism of the phosphonate herbicide glyphosate by a non-nitrate-utilizing strain of Penicillium chrysogenum. Pest Manage. Sci. 57, 815-821.

Kodama, T., Ding, L., Yoshida, M., Yajima, M., 2001. Biodegradation of an s-triazine herbicide, simazine. J. Mol. Catal., B Enzym. 11, 1073-1078.

Koskinen, W.C., Harper, S.S., 1990. The retention process: mechanisms. In: Cheng, H.H. (Ed.), Pesticides in the Soil Environment: Processes, Impacts, and Modeling. SSSA, Madison, WI, pp. 51-78

Krieger, M.S., Merritt, D.A., Wolt, J.D., Patterson, V.L., 1998. Concurrent patterns of sorption-degradation for oryzalin and degradates. J. Agric. Food Chem. 46, 3292-3299.

Laabs, V., Amelung, W., Pinto, A., Altstaedt, A., Zech, W., 2002. Fate of pesticides in tropical soils of Brazil under field conditions. J. Environ. Qual. 31, 256-268.

Lee, P.W., 2003. Sulfentrazone. In: Lee, P.W. (Ed.), Handbook of Residue Analytical Methods for Agrochemicals, vol. 1. John Wiley, Chichester, p. 564.

Leung, L.Y., Lyga, J.W., Robinson, R.A., 1991. Metabolism and distribution of the experimental triazolone herbicide F 6285 [1-[2,4-dichloro-5-[N-(methylsulfonyl) aminophenyl]-1,4-dihydro-3-methyl-4-(difluoromethyl)-5H-triazol-5-one] in the rat, goat, and hen. J. Agric. Food Chem. 39, 1509-1514.

Martinez, C.O., 2006. Biotransformação do herbicida sulfentrazona em solos brasileiros. Dissertação de Mestrado, UNICAMP, Campinas, SP, Brazil.

Midi, 2001. Microbial Identification System Operating Manual. MIDI, Inc, Newark.

Montgomery, D.C., 1991. Design and Analysis of Experiments, 3rd ed. John Wiley, New York.

Moreale, A., van Bladel, R., 1979. Soil interaction of herbicide derived aniline residues: a thermodynamic approach. Soil Sci. 127, 1-9.

Niekamp, J.W., Johnson, W.G., 2001. Weed management with sulfentrazone and flumioxazin in no-tillage soybean (Glycine max). Crop Prot. 20, 215-220.

Nogueira, N.L., Barroso, P.A.V., 1998. Microscopia eletrônica aplicada aos estudos de ecologia microbiana. In: Melo, I.S., Azevedo, J.L. (Eds.), Ecologia Microbiana. Embrapa-CNPMA, Jaguariúna, pp. 279-307.

Ogram, A.V., Jessup, R.E., Ou, L.T., Rao, P.S.C., 1985. Effects of sorption on biological degradation rates of (2,4-dichlorophenoxy) acetic acid in soils. Appl. Environ. Microbiol. 49, 582-587.

Ohmes, G.A., Hayes, R.M., Mueller, T.C., 2000. Sulfentrazone dissipation in a Tennessee soil. Weed Technol. 14, 100-105.

Olson, W.P. (Ed.), 1996. Automated Microbial Identification and Quantitation. Interpharm Press, Buffalo Grove, IL, USA.

Paraíba, L.C., Cerdeira, A.L., Silva, E.F., da Martins, J.S., Coutinho, H.L.C., 2003. Evaluation of soil temperature effect on the herbicide leaching potential into groundwater in the Brazilian cerrado. Chemosphere 53,1087-1095.

Paraíba, L.C., Luiz, A.J.B., Pérez, D.V., 2005. Estimativa da Superfície Específica de Solos e do Coeficiente de Sorção de Pesticidas. Embrapa Meio Ambiente, Jaguariúna, SP, Brazil.

Paraíba, L.C. Fay, E.F., Abakerli, R.B., 2006. Sorção de sulfentrazona em solos brasileiros. In: Silva, C.M.M.S. (Ed.), Avaliação Ambiental e Toxicológica do Herbicida Sulfentrazona: Relatório final projeto FAPESP. Embrapa Meio Ambiente, Jaguariúna, SP, Brazil, pp. 32-37.

Reddy, K.N., Locke, M.A., 1998. Sulfentrazone sorption, desorption, and mineralization in soils from two tillage systems. Weed Sci. 46, 494-500.

SAS Institute Inc., 2004. SAS/STAT® 9.1 Users Guide. SAS Institute Inc, Cary, NC.

Sasser, M., 1990. Identification of bacteria by gas chromatography of cellular fatty acids. MIDI Technical Note 101. Microbial ID, Inc., Newark, DE.

Satterthwaite, F.W., 1946. An approximate distribution of estimates of variance components. Biom. Bull. 2, 110-114.

Scow, K.M., Johnson, C.R., 1997. Effect of sorption on biodegradation of soil pollutants. Adv. Agron. 58, 1-56

Silva, A.A., Oliveira Junior, R.S., Castro Filho, J.E., 1998. Avaliação da atividade residual no solo de imazaquin e trifuralin através de bioensaios com milho. Acta Sci. 20, 291-295.

Sims, G.K., Radosevich, M., He, X.T., Traina, S.J., 1991. The effects of sorption on the bioavailability of pesticides. In: Betts, W.B. (Ed.), Biodegradation: Natural and Synthetic Materials. Spring-Verlag, New York, pp. 120-137.

Sims, G.K., Wolt, J.D., Lehmann, R., 1992. Bioavailability of sorbed pesticides and other xenobiotic molecules. Proceedings of the International Symposium on Environmental Aspects of Pesticide Microbiology. Swedish University of Agricultural Science, Uppsala, Sweden, pp. 159-164.

Singh, P., Suri, C.R., Cameotra, S.S., 2004. Isolation of a member of Acinetobacter species involved in atrazine degradation. Biochem. Biophys. Res. Commun. 317, 697-702.

Smithgrenier, L.L., Adkins, A., 1996. Isolation and characterization of soil microorganisms capable of utilizing the herbicide diclofop-methyl as a sole source of carbon and energy. Can. J. Microbiol. 42, 221-226.

Sommerville, L., 1987. Perspective on side-effects testing. In: Sommerville, L., Greaves, M.P. (Eds.), Pesticide Effects in Soil Microflora. Taylor \& Francis, London, pp. 5-13.

Spadotto, C.A., Hornsby, A.G., 2003. Organic compounds in the environment soil sorption of acidic pesticides: modeling pH effects. J. Environ. Qual. 32, 949-956.

Theodorides, G., Baum, J.S., Holtzman, F.W., Manfredi, M.C., Maravetz, L.L., Lyga, J.W., Tymonko, J.M., Wilson, K.R., Poss, K.M., Wyle, M.J., 1992. Synthesis and herbicidal properties of aryltriazolinones. A new class of pre- and postemergence herbicides. In: Baker, D.R., Fenyes, J.G., Steffens, J.J. (Eds.), Synthesis and Chemistry of Agrochemicals III. ACS Symposium Series 504. American Chemical Society, Washington, DC, pp. 135-146. 
Tuite, J. 1969. Plant Pathology Methods: Fungi and Bacteria. Burgess, Minneapolis, MD. USDA Soil Conservation Service, Soil Survey Staff, 1975. Soil Taxonomy: A Basic System of Soil Classification for Making and Interpreting Soil Surveys. Agric. Handb., vol. 436. U.S. Gov. Print. Office, Washington, DC.

Velini, E.D., 1992. Comportamento de herbicidas no solo. Simpósio Nacional Sobre Manejo Integrado de Plantas Daninhas em Hortaliças. UNESP-FCA, Botucatu, SP, Brazil, pp. 44-64.

Vencill, W.K., 2002. Herbicide Handbook, 8th ed. Weed Science Society of America, Lawrence, KS, pp. 111-406.
Walker, A., Barnes, A., 1981. Simulation of herbicides persistence in soil: a revised computer model. Pest. Sci. 12, 123-132.

Weber, J.B., 1981. Interaction of organic pesticides with particulate matter in aquatic and soil systems. In: Gould, R.F. (Ed.), Fate of Organic Pesticides in the Aquatic Environment. American Chemical Society, Washington, DC, pp. 55-120. 